\title{
Introduction
}

\section{Hybrid Victims}

- These I will remember.

Eileh ezkerah.

I asked to take leave of my father and he granted his permission and left. An Arab sailor in Haifa lifted me to the soil and it granted him leave.

The Holocaust of the Jews of Europe and the Holocaust of the Arabs of the Land of Israel are but one Holocaust of the Jewish people. The two Holocausts stare one another straight in the face.

Of these I will speak.

Eileh adaber.

Avot Yeshurun, HaShever HaSuri Afrikani

(The Syrian-African Rift: Poems)

A transition from a "politics of ideas" to a "politics of identity" is perhaps the major change that Israeli society has experienced in recent years. ${ }^{1}$ Sociologists, historians, political scientists, cultural critics, journalists, political commentators, and public intellectuals all offer different interpretations of this shift including reasons for its periodization. When exactly did this change occur? Was it the result of a single dramatic event or an inevitable by-product of the long and painful process of building a new society? Or perhaps it is just a normal manifestation of an identity crisis that Israel is undergoing fifty years after its establishment. In an immigrant society aspiring to be a Jewish state rather than a state of its citizens, the issue of collective identity becomes all the more important for its members, and questions of identity related to the dialectics democratic versus theocratic, Western versus Oriental, collectivist versus liberal capitalist, or Jewish versus civil are constantly raised in an atmosphere of heated public debate verging — some would claim — on a culture war. 
Although Edward Said claims that the issue of identity, and especially what he sees as the obsessive academic preoccupation with it, "is boring," 2 one cannot ignore the feeling that this "obsession" — what Stuart Hall calls "a veritable discursive explosion in recent years around the concept of identity" 3 becomes an issue when it is in crisis. It is also clear that despite Israel's tendency to see itself as unique, its contemporary crisis of identity is neither unique nor exclusive. The issue of identity, as Hall observes, has been the issue of the twentieth century. It defines contemporary politics and has become a site for contestation for many of this century's struggles. "We live in a world where identity matters," Paul Gilroy observes. The word identity itself, he elaborates, "has acquired a huge contemporary resonance, inside and outside the academic world.... Principally, identity provides a way of understanding the interplay between our subjective experience of the world and the cultural and historical settings in which that fragile subjectivity is formed." " This interplay explains the reason why some contemporary writers argue that the notion of identity should also be analyzed in the context of globalization. In a world where the boundary-setting capacities of the nation-state have been eroded, "the distinctions between inside and outside, citizen and alien, self and other" 5 are rendered problematic. The new kind of social space that has been created in our world - through the growth of crisscrossed economies and culturesproduces growing tension between local and global identities, and between heterogeneity and homogeneity.

This book is not a sociological work, nor does it pretend to provide an allencompassing, comprehensive explanation for the social, political, and cultural processes that are currently making their mark on Israeli society. Rather, it deals with the reflection, projection, and construction of debates revolving around Israeli identity in one of the major forms of visual representation of Israeli society: cinema. In conceptualizing Israeli cinema as a representational form of identity construction I follow Hall's argument that we should think of identity "as a 'production' which is never complete, always in process, and always constituted within, not outside representation." ${ }^{6}$ Sameness and difference, the main components of laying claim to identity, are marked symbolically through the representational system of cinema that both projects and reproduces the social, political, and cultural inclusion or exclusion of certain groups of people.

Ella Shohat's classic book, Israeli Cinema: East/West and the Politics of Representation, ${ }^{7}$ was a breakthrough in its treatment of Israeli cinema as a representational system through which Israeli-Zionist ideology has been repro- 
duced and perpetuated, particularly around the question of the Orient (as related both to the Palestinians and to Mizrahi Israelis). Since the publication of Shohat's pioneering work, Israel has undergone some dramatic changes, among them the Intifada (the Palestinian popular uprising), the beginning of the peace process, the Oslo Accords, the assassination of Prime Minister Yitzhak Rabin, the rise to power of Binyamin Netanyahu's Likud-dominated government, and the growing power of the religious and religious-ethnic parties. In addition, due to a lack of relevant films on the topic at the time of the book's writing, Shohat did not devote substantial space to the representation of the Holocaust, which I, like many other Israeli scholars, see as the main formative force in the shaping and construction of Israeli identity. The present book, obviously influenced by my own identity politics as a child of Holocaust survivors who lives in Israel, aspires to fill those gaps left by Shohat's otherwise very comprehensive book. Unlike Shohat's book, however, this book is not a historical and ideological in-depth study of the overall corpus of Israeli cinema from its inception. Rather, it is an attempt both to discuss the projection and negotiation of Israeli identity through an analysis of major Israeli films, particularly from the 1980 os and 1990s, that constitute unique sites of struggle over identity formation and meaning and to open and broaden further the public space for debating this issue. The chapters in this book all deal, in different ways, with the question of identity, including notions of fluidity and contingency - that is, identity as formed in particular historical circumstances.

Identities in contemporary Israel, as in most of the contemporary world, derive from a multiplicity of sources - nationality, ethnicity, social class, gender, sexuality, and religion - that may conflict and thus lead to a society marked by fragmentation and polarization, which is the current state of affairs in Israel. This book focuses on three major foundational sites of the struggle over Israeli identity: the Holocaust, the question of the Orient, and (in an ironic historical twist of the "Jewish question") the so-called Palestinian question. The films discussed here raise fundamental questions about the identity of Jewish Holocaust survivors and their children-the "second-generation" Mizrahim (particularly the second generation of Mizrahi Israelis) and Palestinians. The book does not treat each identity group as a separate and coherent entity but rather attempts to see the conflation and interplay (and conflict) between them.

All the identities represented in the films that I discuss are marked by victimhood. And indeed, as in the multicultural wars dividing the contemporary 
ethnic landscape of American society, so in Israel discussion of racism is often displaced by competition over victimization. Contemporary Israeli identity politics is based on perceived and real victimhood that demands recognition and acknowledgment of victimization. The 1998 appeal for forgiveness by Ehud Barak from the Mizrahim for the way they were treated by the former Mapai (a predecessor of today's Labor Party) is a case in point. ${ }^{8}$ What connects the Mizrahim with Holocaust survivors and Palestinians is a strong sense of being victimized by the Zionist state. ${ }^{9}$ In recent years the hegemonic IsraeliJewish narrative has been oscillating between the former myths of voluntary sacrifice and heroism on the one hand and the emerging appeals for recognition of involuntary past suffering on the other. To a large extent, Israeli society has become a society that thrives on victimhood and elevates it to the level of "civil religion." This was most evident in the recent Likud-dominated government, which viewed itself as a coalition of past victims or, in the language of contemporary Israeli journalistic rhetoric, a coalition of minorities composed of previously oppressed and stigmatized groups (ultra-Orthodox, Mizrahim, Russian immigrants, and the Israeli Right). ${ }^{10}$ This coalition points to the centrality of victimology in contemporary Israeli identity politics, which, ironically, fails to acknowledge Israel's primary victims - the Palestinians. In fact, the basis of the identities of the Mizrahim and the Holocaust survivors resembles that of the Palestinians - the experience of spatial/geographic and cultural/spiritual displacement.

Identity, particularly in the case of extreme forms of national and/or ethnic conflict, is marked by inclusion and exclusion, "us" and "them." The three main identities discussed in this book are thus viewed as constantly playing off each other, as well as against an imaginary and imagined Israeli collective identity (Sabra, Ashkenazi, associated with Israeli leftist politics). Their struggle for hegemony, or at least recognition, is in most cases a struggle for the recognition of suffering and victimhood rather than voluntary heroic sacrifice.

Israel, as portrayed in this book, is the meeting point of conflicting and conflating identities. Hence Israel is represented not only as a site of contention and struggle but also as a site of meeting and negotiation, voluntary or not. Reality and necessity in history have turned Israel into a meeting point, or even melting pot, of conflating identities. Yet, these identities, according to Hall, pronounced in a different context "far from being eternally fixed in some essentialized past, ... are subject to the continuous 'play' of history, culture and power." 11

The historical encounter between the Israelis (the new Jews) and the Holo- 
caust survivors who (voluntarily or not) immigrated to Palestine/Israel is one example of what Hall is referring to. Some of the films discussed in this book echo conflictual moments associated with this traumatic meeting, which has been insightfully described by Idith Zertal as "the return of the diaspora in its role as the unconscious of Zionism." ${ }^{12}$ In Amos $\mathrm{Oz}$ and Dan Wolman's $M y$ Michael (see chap. 5) Hanna Gonen's insanity and abnormality is projected, screened, and reflected by the character of Duba Glick, the crazy Holocaust survivor and a character who populated the childhood space of the second generation. Dan Wolman's Hide and Seek (see chap. 6) similarly includes the story of the crazy, dirty, and stinking Holocaust survivor, Yankush, whose neighbors force him to take a shower despite his horror and shouts of "gas, gas." The violence practiced by the "vatikim" (oldcomers) and the Sabras against this particular Holocaust survivor is a prelude to the violence afflicted by members of the Haganah (the crème de la crème of the Zionist Yishuv) on the Jewish and Arab homosexuals in Hide and Seek. As my analysis shows, in Israeli cinema, violence as well as different practices of "purification" are constantly inflicted and forced on the "others" excluded from Israel's imagined collective identity.

In contemporary Israeli cinema, there is a growing openness to marginal and minority identity groups, and a transition to self-representation of these groups - as in the film Shchur (1994) and the second-generation Holocaust films (see chaps. 3 and 4) - is already taking place. This book, however, does not explore all the issues related to the representation of minority groups in Israeli cinema. It does not deal with the rise of religion as a major force in Israeli society, culture, and politics; the new wave of immigration from the former Soviet Union; the Ethiopian immigration; and foreign workers, which as yet are not salient topics in Israeli film. It also does not discuss contemporary tensions between global (mostly American) and local identities. The representation of women in Israeli cinema, as well as Israeli films made by women, are not discussed in this book as a special topic. However, a feminist critique is vigorously employed throughout the book and particularly in chapters 4-6.

As identity politics is intimately linked with the politics of representation, I chose to open this book with a Hollywood-produced film: Exodus. The construction of the new Jew by American popular imagination, as reflected in Exodus, influenced the construction of and focus on the Sabra by dominant Israeli cinema, particularly in what Shohat calls the "heroic-nationalist genre." In chapter 1 I outline the characteristics of the "new Jew" as established by Hollywood's cinematic epic Exodus, which has become an inspiring model 
text for this genre in Israeli cinema. The discussion approaches the film as an attempt to construct a Zionist myth, exploring the film's ideological tensions in its attempt to reenact the foundational Exodus narrative to support the Zionist project and to eliminate the "Palestinian question." I show how the film reinforces the universalist and liberationist reading of the Exodus myth while suppressing its reading as a paradigmatic narrative of colonization.

In chapter 2 I provide an overview of the space that the Holocaust occupies in Israeli collective memory and consciousness, as well as its place in the process of negotiating and constructing Israeli identity. I focus on the establishment of the second generation as an identity group and explore the philosophical, national, and ethnic roots of Israeli society's recognition and acceptance of these children of Holocaust survivors and Jewish refugees as a distinct generational entity. The discussion also explores the brief history of the representation of the Holocaust in Israeli cinema where, like in many other domains of Israeli culture, it has been silenced and repressed for many years. A significant change can be traced in the late 1980 only with the appearance of Orna Ben Dor's documentary Because of That War (1988), which deals with Israeli musicians Yehuda Poliker and Ya'akov Gilead, both children of Holocaust survivors. Poliker and Gilead's joint rock album, titled Ashes and Dust, introduced the Holocaust as a legitimate theme in Israeli popular culture, and together with Ben Dor's film it helped establish the second generation as an identity group.

In chapter 3 I analyze in depth the representation of the Holocaust in three major documentary films made by second-generation Israeli filmmakers: Orna Ben Dor's Because of That War, Asher Tlalim's Don't Touch My Holocaust (1994), and Tzipi Reibenbach's Choice and Destiny (1994). Using the notion of postmemory as elaborated by Marianne Hirsch, I discuss the films as constituting a social and cultural document on Israeli society by projecting the society's attitude toward the memory of the Holocaust and articulating the role that the Holocaust plays in shaping Israeli identity. I also suggest that what Hirsch calls the aesthetics of postmemory, a diasporic aesthetic of temporal and spatial exile that needs simultaneously to rebuild and to mourn, is at the center of these films.

Chapter 4 reverts to the second generation of Israeli Mizrahim, studying in depth the film Shchur (1994), written by Hanna Azulay Hasfari, a child of Moroccan immigrants to Israel, and directed by her Ashkenazi husband, Shmuel Hasfari. Shchur, told from the point of view of its woman protagonist Rachel, the youngest and only Sabra child of a family of Jewish immigrants 
from Morocco, is the first "art film" associated with Oriental ethnicity. The film is groundbreaking particularly because it is the first Jewish North African film made in Israel about what has come to be known in Israeli public discourse as "second Israel" - namely, culturally and economically poor Israel dominated by Mizrahi "mentality" and concentrated in remote development towns and in the slums of Israel's big cities.

In chapter 5 I explore yet another aspect of Orientalism in Israeli culture through the examination of the novel and film My Michael. Unlike more traditional analyses of the novel and the film, this chapter, written from a feminist perspective, locates the two texts within the context of colonial-Orientalist discourse. Through a comparison of feminist/colonialist discourses in $M y$ Michael, as well as its positioning in the context of other colonial texts (some of which have also been adapted into colonial and postcolonial films), I suggest a new reading of one of the canonical texts of both Israeli literature and Israeli cinema.

Chapters 6 and 7 comprise a discussion of the fears of "forbidden love" between Israeli Jews and Palestinians as they are expressed and transgressed in the relatively large group of films in Israeli cinema that deal with this theme. In these chapters I expose the sexual economy and ideology deeply embedded in these love stories and trace a line of progression from My Michael to the recent Day after Day (1998) by Amos Gitai-a clear transition from fantasy to materialization of fantasy. I argue that although Hide and Seek, with its open treatment of doubly forbidden love (homosexual and interracial), features perhaps the ultimate transgression in this genre, Day after Day, with its matter-of-fact treatment of its protagonist Mosh/Mussa, the Palestinian-Israeli hybrid (the son of a Jewish mother and Palestinian father), is the most transgressive film. Day after Day is the only optimistic film in the forbidden love genre because it implicitly suggests that the existence of the "hybrid fruit" promises that an Israeli multicultural and binational identity has the potential to become unforbidden. It is on this utopian note that the book ends. 
THIS PAGE INTENTIONALLY LEFT BLANK 
Identity Politics on the Israeli Screen 
THIS PAGE INTENTIONALLY LEFT BLANK 